Kabul Tarihi:20.12.2016

\title{
Yerel Halkın Bölgesel Kalkınma Açısından Yeşil Yol Projesine ve Turizme Bakışı: Yavuzkemal Belde Merkezi Örneği
}

\section{Local Residents' Perspective on the Green Road Project and Tourism from the Point of Regional Development: The Case of Yavuzkemal Town Center}

\author{
Sercan YILDIZ \\ İstanbul Üniversitesi \\ Sosyal Bilimler Enstitüsü \\ E-posta: srcn_yldz@hotmail.com \\ Orcid Id:0000-0001-5246-6855
}

\begin{abstract}
Öz
$\mathrm{Bu}$ çalışmada, Yavuzkemal belde merkezinde yaşayan yerel halkın mevcut turizm tutumlarının, Doğu Karadeniz Projesi (DOKAP) kapsamında bir turizm faaliyeti olarak yürütülen Yeşil Yol Projesi'ne yönelik algıları üzerindeki etkisi araştırılmıştır. Çalışmada ayrıca, belde merkezinde yaşayan yerel halkın demografik ve sosyo-ekonomik özelliklerine göre bölgesel kalkınma açısından son derece önemli olan turizme karşı bakış açıları ve tutumları incelenmiştir. Bu amaçla, belde merkezinde yaşayan yerel halktan 131 anket verisi toplanmış ve çalışma kapsamında belirlenen araştırma hipotezleri test edilmiştir. Çalışma sonuçları, belde merkezinde yaşayan yerel halkın turizme karşı mevcut bakış açıları ve tutumlarının, Yeşil Yol Projesi'ne yönelik algıları üzerinde etkili olduğunu ortaya çıkarmıştır. Çalışma sonuçları ayrıca, yerel halkın demografik ve sosyo-ekonomik özellikleri açısından bölgesel turizm faaliyetlerine karşı tutumlarında, anlamlı farklılıklar olduğu göstermektedir.
\end{abstract}

Anahtar Kelimeler: Bölgesel kalkınma, turizm, doğu karadeniz projesi, yeşil yol projesi, yavuzkemal.

\begin{abstract}
In this study, the effect of current tourism attitudes of the local people living in Yavuzkemal town center on The Green Road Project that has been executed as a tourism activity within The Eastern Black Sea Project (DOKAP) were investigated. In this study, the attitudes and perspectives towards tourism, which is extremely important in terms of regional development were examined according to the demographic and socio-economic characteristics of the local people living in Yavuzkemal town center. With this purpose, the data were collected from 131 local residents living in town center using survey method and the research hypotheses set by considering the aims and the scope of this study, were tested. The results of the study reveal that, the current perspectives and attitudes of the local people living in the center of the town towards tourism are influential on their perspectives on The Green Road Project. The study results also show that, there are significant differences in local residents' attitudes towards regional tourism activities in terms of their demographic and socio-economic characteristics.
\end{abstract}

Keywords: Regional development, tourism, the eastern black sea project, the green road project, yavuzkemal. 


\section{Giriş}

20. yüzyılın ikinci yarısından itibaren turizm, dünya ekonomisinde en hızlı gelişen ve genişleyen sektörlerden biri haline gelmiştir. Gelişen ve genişleyen turizm sektörünün kaynaklarının etkin bir biçimde kullanılması, bölgeler arasındaki dengesizliklerin giderilmesi ve bölgesel kalkınmanın sağlanması açısından önemlidir (Çeken, 2008). Türkiye'de turizm sektörü, 1980 yılından sonra büyük bir gelişme göstermiş ve ülke açısından dış açığın giderilmesinde, işsizliğin azaltılmasında, ödemeler dengesinin iyileştirilmesinde ve ulusal veya bölgesel kalkınmada önemli bir paya sahip olmuştur (Çımat ve Bahar, 2003). Ancak günümüzde gelişmekte olan ülkelerin temel sorunu, sahip oldukları mevcut turizm kaynaklarını etkili bir şekilde kalkınma hamlelerine dönüştürememesidir (Çeken, 2008). Bu sebeple, gelişmekte olan ülkelerin mevcut turizm potansiyellerini değerlendirebilecek, bölgeler arasındaki dengesizlikleri ortadan kaldırmaya yönelik olarak turizm teşvik politikalarına ve kalkınma ajansları gibi yerel kurumsallaşmalara intiyaç durulmaktadır (Kayasü ve diğ., 2003; Arslan, 2005). Bu çerçevede düşünüldüğünde, Onuncu Kalkınma Planı içerisinde, Doğu Karadeniz Kalkınma Ajansı (DOKA) tarafından, Doğu Karadeniz Projesi kapsamında bir turizm faaliyeti olarak yürütülen Yeşil Yol Projesi, bölgeler arasındaki dengesizliklerin giderilmesi ve mevcut turizm olanaklarının geliştirilmesi adına önem arz etmektedir. Ancak, yıllardan bu yana süregelen kalkınma politikalarını en etkin şekilde uygulayabilmek ve turizmin bölgesel kalkınma üzerindeki etkisini en üst düzeye çıkarabilmek için, yerel halkın turizme karşı tutum ve davranışlarını bilmek son derece önemlidir. Alanyazında yapılan birçok çalışma, bölgesel kalkınma ajansları ve bölgesel kalkınma projeleri kapsamında değişen ve gelişen çevrenin bölgede yaşamını sürdüren yerel halk tarafından değerlendirilmesi sonucu, yerel halkın turizme karşı bakış ve tutumlarında önemli değişiklikler olabileceği sonucunu ortaya koymuştur (Butler, 1980; Lankford ve Howard, 1994). Ayrıca alanyazında yapılan çalışmalar, bölgesel turizm faaliyetleri çerçevesinde yerel halkta meydana gelen demografik ve sosyo-ekonomik değişimlerin, yerel halkın turizme karşı bakış ve tutumlarında etkili olduğu sonucunu da ortaya çıkarmıştır (Wang ve diğ., 2006). Bu bilgiler ışığında çalışmanın öncelikli amacı, Yavuzkemal belde merkezinde yaşayan yerel halkın mevcut turizm tutumlarının, Yeşil Yol Projesi'ne yönelik algıları üzerindeki etkisinin araştırılmasıdır. Belde merkezinde yaşayan yerel halkın mevcut turizm tutumlarının, Yeşil Yol Projesi'ne olan pozitif bakış açıları ve tutumları üzerinde etkili olduğu düşünülmektedir. Çalışmanın bir diğer amacı, Yavuzkemal belde merkezinde yaşayan yerel halkın demografik ve sosyo-ekonomik özelliklerine göre bölgesel kalkınma açısından son derece önemli olan turizme karşı bakış açıları ve tutumlarının incelenmesidir. Çalışma bulgularının proje yürütücüleri ve araştırmacılara, yapılacak sonraki çalışmalarda sonuçları karşılaştırılması açısından önemli bilgiler sunacağı öngörülmektedir.

\section{Kavramsal Çerçeve ve İIgili Çalışmalar \\ 2.1. Bölgesel Kalkınma Kavramı ve Turizm Teşvik Politikaları}

Türk Dil Kurumu'na göre bölge, sınırları idari, ekonomik birliğe, toprak, iklim ve bitki özelliklerinin benzerliğine veya üzerinde yaşayan insanların aynı soydan gelmiş olmalarına göre belirlenen toprak parçası olarak tanımlanmaktadır (TDK). Kalkınma ise, içinde bulunulan durumdan ya da bir önceki konumdan hareket ederek, değişime girmeyi öneren dinamik bir kavramı ifade etmektedir (Tolunay ve Akyol, 2006). Bir diğer tanıma göre kalkınma, üretim ve kişi başına düşen gelirin artması ile birlikte, ekonomik ve sosyokültürel yapıda oluşan değişimdir (Savaş, 1979). Bu iki kavram çerçevesinde bölgesel kalkınma, ülke bütününde yer alan bölgelerin, çevre bölgeler ve dünya ile karşılıklı etkileşimi ile oluşan, bölge vizyonunu dikkate alan, katılımcılık ve 
sürdürebilirliği temel ilke edinen ve insan kaynaklarının geliştirilmesi yoluyla bölge refahının yükseltilmesini amaçlayan çalışmalar bütünü olarak tanımlanabilir (Özyücel, 2008; Kök, 2010).

Tüm bu bilgiler ışığında bir ülke içerisindeki her bir bölgenin, aynı derecede kalkınma başarısını göstermesini beklemek, biraz iyimser bir yaklaşım olacaktır. Bir ülkenin çeşitli bölgelerinde meydana gelen her çeşitten eşitsizlik, bölgeler arası dengesizlik sorununu ortaya çıkarmaktadır (Tutar ve Demiral, 2007; Özel, 2009). Ortaya çıkan bu bölgesel dengesizlik, ekonomiye bağlı olarak, birçok önemli toplumsal sorunları beraberinde getirmektedir. Bu sebeple, bölgelerarası farkları azaltmada bölgesel politikaların geliştirilmesi ve uygulanması son derece önemlidir. Bölgesel kalkınma politikalarının uygulanmasında gözetilen temel amaç, bölgeler arasında zamanla oluşan sosyo-ekonomik gelişmişlik dengesizliklerini ortadan kaldırmaktır (Kök, 2010). Bu türlü politikalar ayrıca, bölgesel ve yerel aktörlerce tasarlanan ve hayata geçirilen bir bölgesel gelişme stratejisinin inşasına ve bölgenin asli unsurlarının anlamlı bir şekilde yeniden belirlenmesine de olanak verecektir (Özel, 2009). Ancak gelişmiş ülkelerde uzun yıllardan beri üzerinde önemle durulan ve geniş ölçüde uygulama olanağı bulan bölgesel planlama ve bölgesel kalkınma politikaları, maalesef gelişmekte olan ülkelerde pek rağbet görmemiş ve çeşitli altyapı yatıımlarının desteklenmesi ile sınırlı kalmıştır (Arslan, 2005). Ayrıca bağımsız yerel kurumların olmaması ve var olan kurumların işlevlerinin sınırlı kalması nedeniyle, kalkınma planları bölgesel farklılıkları azaltmanın aksine, artmasına neden olmuştur (Oskay ve Kubar, 2007). Bu sebeple Türkiye'de, daha çok il planlaması tercih edilmiş ve bölgesel gelişmişlik farklılıklarının giderilmesi için kalkınmada öncelikli yöreler uygulaması ön plana çıkmıştır (Arslan, 2005). Bu uygulamada, bölge ve yörelere göre hangi sanayi dallarının teşvik edileceği veya gelişmesinin engelleneceği üzerinde durulmuştur (Gökçen, 1987).

Turizm bu anlamda, 1950'li yıllardan günümüze kadar birçok kalkınma ve teşvik planı içerisinde, teşvik edilecek sektör olarak yer almıştır. 1950 yılında çıkarılan "5647 Sayılı Turizm Müesseseleri Teşvik Kanunu" turizm sektörünün geliştirilmesi amacıyla çıkarılan ilk yasal düzenleme olma özelliğini taşımaktadır. Bu yasada, hangi işletmelerin "Turizm Müessesesi" olacakları, hangi işletmelerin yasada bahsi geçen teşvik tedbirlerinden yararlanacağı ve turizm işletmelerinin denetlenmesine ilişkin ilkelere ait düzenlemelerden bahsedilmiştir. Turizm endüstrisindeki yatııımları teşvik amacıyla, 1953 yılında "6086 Sayılı Turizm Endüstrisini Teşvik Kanunu" adıyla ikinci bir teşvik kanunu daha çıkarılmıştır. Bu kanun ile turizm alanında yatırım yapacak özel teşebbüslere on yıl süreyle vergi muafiyetinden yararlanma gibi çeşitli teşvik politikaları uygulanmıştır. 1982 yılında yürürlüğe giren ve "2634 Sayılı Turizm Teşvik Kanunu" adıyla çıkarılan teşvik politikasında, turizm alanları ve turizm merkezlerinin belirlenmesi ve bu alan ve merkezlerde bulunan kamu arazilerinin yatırımcıya tahsisi konuları yer almıştır. Bu teşvik kanunu, bugünkü turizm sektörünün oluşmasında büyük rol oynamıştır (Toker, 2007). Turizm sektörü, 1985 yılı itibarı ile "Kalkınmada Özel Önem Taşıyan Sektör" kapsamına alınmış ve bugün, Onuncu Kalkınma Planı (2014-2018) içerisinde yürütülen Doğu Karadeniz Projesi kapsamında turizm alanında bölgeye önemli bir marka değeri kazandıracağı düşünülen ve yaylaları birbirine bağlaması öngörülen Yeşil Yol Projesi ile turizmin, bölgesel kalkınma üzerindeki önemi bir kez daha vurgulanmıştır.

\subsection{Turizmin Bölgesel Kalkınma Üzerine Etkisi ve Yeşil Yol Projesi}

Turizm, gelişmiş veya gelişmekte olan ülkelerde, bölgelerin ekonomik büyüme ve kalkınmalarını sağlayan önemli bir sektördür (Künü ve diğ., 2015). Ayrıca gelirin tabana yayılması, dengeli kalkınmanın sağlanması ve her kesimin bundan pay almasına 
imkân sağlayan bir sektör olmasından dolayı turizm, bölgesel olarak ekonomik ve sosyal uçurumları da ortadan kaldırmaktadır (Durgun, 2006). Bu sebeple, turizm faaliyetlerinin geliştirilmesi, atıl kalmaması için yörelerin bölgesel teşvik kapsamına alınması ya da bu alanlara bizzat devletin yatırımlar yaparak, yöreye yönelik yatırımların özendirilmesi son derece önemlidir. Geniş çerçevede düşünüldüğünde, endüstriyel gelişmeye uygun olmayan alanlarda turizmin bir ekonomik faaliyet olarak geliştirilmesi, ülkenin bir tarafından kazanılan zenginliğin diğer taraflarda harcanması yoluyla zenginliğin bu yörelere aktarılması ve buralarda refah düzeyinin yükselmesine yardımcı olması da muhtemeldir (Yeşiltaş ve Öztürk, 2008). Bu durum, özellikle Türkiye gibi turizmin belli bölgelerde kümelendiği ülkelerde hayati önem taşımaktadır.

Turizmin bir diğer bölgesel etkisi ise, ülkeye gelen turistlerin yapmış oldukları bölgesel seyahatlerin, alt yapı hizmetlerine olumlu yansımasının sonucu olarak, o bölge vatandaşlarını kitle ulaştırma imkânlarında yüksek standartlara, elektrik, su vb. altyapı hizmetlerinde üstün bir düzeye ve belki de başka bir şekilde sahip olmayacakları alışveriş ve eğlence merkezlerine kavuşturmasıdır (Bahar ve Kozak, 2006). Bütün bu olumlu gelişmeleri dikkate alarak, bölgesel dengesizlikleri gidermek bağlamında yerel dinamikleri doğrudan etkileyerek, yerel ve bölgesel kalkınma açısından yeni şartlar ve fırsatlar yaratma bağlamında bölgesel turizm potansiyeli değerlendirilmelidir (Yeşiltaş ve Öztürk, 2008).

Doğu Karadeniz Bölgesi için turizm, önemli bir kaynaktır. Bölge, genel itibarıyla turizm alanı olarak algılanmaktadır. Turizmdeki gelişmelerin bu bölgelerde sürekli kılınması için doğa ile dost işletmelerin kurulması, bölgedeki kültür varlıklarının korunarak geliştirilmesi ve turizme kazandırılması, bölge yaylalarının karakteristiğini yansıtan binaların ve turizm merkezlerinin imar planlarının, Doğu Karadeniz Bölgesi'nin doğal güzelliğine uygun şekilde yapılması son derece önemlidir (Dokap, 2014). Bu sebeple Doğu Karadeniz Kalkınma Ajansı tarafından, Doğu Karadeniz Projesi kapsamında bir turizm faaliyeti olarak yürütülen Yeşil Yol Projesi, büyük önem arz etmektedir. Yeşil Yol Projesi, Doğu Karadeniz Turizm Master Planında (TR90) bölgesinin en yoğun turist çeken üç alanı (Sümela Manastırı, Uzun Göl, Ayder Yaylası) dışında kalan ve turizm potansiyeli bulunan yaylaları birbirine bağlayacak, kuzey-güney yönlü bağlantıları da olan, doğu-batı yönlü bir ana ulaşım aksının devreye sokulması adına önerilen bir "Yayla Koridoru" projesidir (Doka, 2014). Yeşil Yol Projesi ile bölgenin doğal dokusu korunarak, yaylalarda yapılacak evlerin, turistik tesislerin ve hizmet amaçlı yapıların yöre şartlarına en uygun mimari proje tiplerinin belirlenmesi, uygulanması ve bu hususta kaçak yapıların önlenmesi adına gerekli tedbirlerin alınması amaçlanmaktadır (Dokap, 2014). Ancak bu noktada belki de en önemli husus, bu tür çalışmalar yapılırken, yerel halkın turizmin gelişimine karşı tutumlarının bilinmesi ve bu bilgiler ışığında gerekli adımların atılmasıdır (Eren ve Aypek, 2012). Turizmin bölgesel kalkınma üzerine etkilelerinin en üst seviyeye çıkarılabilmesi, geçmişten günümüzü süregelen sürdürülebilir turizm politikalarının ve çalışmalarının gerçekleşebilmesi ve turizmin olumlu etkilerinin artılabilmesi açısından yerel halkın görüş ve önerilerinin dikkate alınması, son derece önemlidir. Uygulanan turizm teşvik politikaları ve projeleri neticesinde gelişecek ve değişecek doğal çevre, aynı zamanda bu bölgelerde yaşayan yöre insanları tarafından da kullanılmaktadır. Dolayısıyla turizm hareketi yerel halka ait yaşamsal döngünün bir parçası durumunda olup, yerel halkın yaşamını çok boyutlu ve değişken olan sosyo-ekonomik, kültürel ve çevresel açılardan ciddi şekilde etkilemektedir (Alaeddinoğlu, 2008). Meydana gelen bu etkiler, bilimsel olarak birçok çalışmanının konusu olmuştur. Örneğin Butler (1980), yapmış olduğu "Turizm Alanı Yaşam Döngüsü" isimli çalışma ile birlikte, turizmin bölgesel olarak gelişmesinin, yerel halk üzerindeki etkilerini bilimsel olarak açıklamaya çalışmış, turizm bölgelerinde yaşayan halkın başlangıçta turizmin bölgeye olan ekonomik etkileri ve 
yerel halkın turiste olan sempatileri nedeniyle halkın turizme karşı olumlu yaklaşımlar sergilediğini; ancak zaman geçtikçe, turizmin ekonomik, sosyal ve çevresel etkilerinin rahatsızlık verici duruma gelmesi nedeniyle gelişim sürecinin durağanlaşmasının veya gerilemesinin söz konusu olduğu sonucuna varmıştır (Türkmen ve Dönmez, 2015). Andereck ve Vogt (2000), yapmış oldukları çalışma ile birlikte, özellikle turizmin etkili olduğu küçük bölgelerde, turizmin yerel halk üzerinde bırakacağı olumsuz etkilerin bilindiği; ancak bu olumsuz etkiler ne olursa olsun yerel halkın her zaman turizmi destekleme yaklaşımı içerisinde olduğunu ortaya çıkarmıştır. Wang ve Pfister (2008), Washington'da yaptığı çalışmada, turizmin gelişme gösterdiği bölgelerde yaşayan yerel halkın, turizmin kendilerinde yarattığı demografik ve sosyo-ekonomik değişimleri dikkatle değerlendirdiğini, meydana gelen etkilerin fayda sağlamaya başlaması ile yerel halkın turizme karşı olumlu yaklaşım sergilediklerini, meydana gelen etkilerin zarar yarattığı durumlarda ise turizmin bölgesel gelişimine karşı olumsuz yaklaşım sergilemeye başladığını ortaya çıkarmıştır. Yakın zamanda yapılan bir diğer çalışmada ise Woo ve diğ. (2016), turizmin sadece yerel halkın tutum ve davranışlarını etkilemediği, aynı zamanda yerel halkın yaşam kalitesi üzerinde de etkili olduğunu, benzer şekilde, eğer yerel halk ve turizm paydaşları turizmden fayda sağlıyorsa, bu durumun memnuniyet yarattığı ve turizmin olumsuz etkilerinin göz ardı edildiği sonucunu ortaya çıkarmıştır.

\section{Araştırmanın Yöntemi}

$\mathrm{Bu}$ çalışmada, araştırmanın amacına uygun olarak nicel araştırma yönteminden yararlanılmıştır. Veriler anket tekniği ile toplanmıştır. Araştırmaya katılacak kişiler, olasılıklı olmayan örnekleme türlerinden, kolayda örnekleme yöntemi kullanılarak belirlenmiştir. Anket formunda yer alan sorular, araştırma hedefine uygun bir şekilde belirlenmeye çalışılmış ve soruların kısa ve anlaşılır olmasına özen gösterilmiştir. Yavuzkemal beldesi, Giresun ili, Dereli ilçesine ait bir belde olup, Giresun'a yaklaşık 60 $\mathrm{km}$ mesafede bulunmaktadır. Beldede turizm henüz tam olarak gelişememiştir. Yeşil Yol Projesi kapsamında Yavuzkemal beldesi, önemli bir turizm merkezi olarak düşünülmektedir. Belde, Doğu Karadeniz Bölgesinin ve Giresun ilinin en önemli yaylalarından olan Kümbet ve Bektaş yaylaları sınırları içerisinde bulunmaktadır. Beldede daha çok doğa ve yayla turizmi hâkimdir. Sert geçen kış döneminde Yavuzkemal beldesinin en yoğun yerleşim alanı, belde merkezidir. Bu sebeple çalışmanın verileri, Şubat-Mart ayları arasında belde merkezinden toplanmıştır. Belde belediyesi verilerine göre belde merkezinin nüfusu, Şubat-Mart ayı itibarı ile 200 kişidir. Bu sayı üzerinden örneklem sayısı, bilinen evren formülü $\left(n=N t^{2} p q^{2} / d^{2}(N-1)+t^{2} p q\right)$ ile 130 kişi olarak hesaplanmıştır (Baş, 2001). Hipotez testleri, belde belediyesi tarafından toplanan 131 anket verisi üzerinden gerçekleştirilmiştir.

Yeşil Yol Projesi, Doğu Karadeniz Bölgesi'nin mevcut turizm olanaklarını geliştirmeyi amaçlayan bir "Yayla Koridoru" projesi olarak yürütülsede, zaman zaman proje yürütücüleri ve yerel halkı karşı karşıya getirmektedir. Ancak, proje kapsamında herhangi türden bir olumsuzluk, Yavuzkemal beldesi açısından yaşanmamıştır. Bu durumun altında, Yavuzkemal beldesi yerel halkının turizme karşı bakış açıları ve tutumlarının yattığı düşünülmüş ve " $H_{1}$ : Katılımcıların Yavuzkemal beldesine yönelik mevcut turizm tutumları, Yeşil Yol Projesi'ne karşı algılarını etkilemektedir." araştırma hipotezi test edilmiştir. Aynı veya farklı bölgelerde yürütülmesi muhtemel benzer proje ve/veya teşvik politikalarının, ilgili bölge açısından öneminin kavranması adına, yerel halkın turizme karşı bakış ve tutumlarını etkileyen faktörlerin bilinmesi önemli olabilir. Bu noktada, özellikle eğitim seviyesinin, turizmin bölgesel kalkınma üzerine etkisini idrak edebilmek açısından önemli bir değişken olduğu düşünülmüş ve belde merkezi yerel halkının eğitim seviyesine göre turizm tutumları arasında anlamlı bir farklılık olup 
olmadığını araştırmak amacıyla, " $\mathrm{H}_{2}$ : Katılımcıların eğitim düzeyi özelliklerine göre turizm tutumları arasında anlamlı farklılık vardır." araştırma hipotezi test edilmiştir. Turizm talebinin bir unsuru olan satın alma gücü, yerel halkın aylık gelirinden ortaya çıkmaktadır. Benzer şekilde aylık gelirin, yerel halkın turizme karşı bakış ve tutumları üzerinde etkili olan bir diğer önemli değişken olduğu düşünülmektedir. Bu sebeple, belde merkezi yerel halkının aylık gelirine göre turizm tutumları arasında anlamlı bir farklılık olup olmadığını araştırmak maksatıyla, " $H_{3}$ : Katılımcıların aylık gelir düzeyi özelliklerine göre turizm tutumları arasında anlamlı farklılık vardır." araştırma hipotezi test edilmiştir. En nihayetinde yıllık tatil sıklığı, turizm bilincinin oluşması açısından önemlidir. Bu bilincin, turizmin bölgesel kalkınma açısıdan öneminin anlaşılabilmesi adına etkili olduğu düşünülmektedir. Bu sebeple, belde merkezi yerel halkının yıllık tatil sıklığına göre turizm tutumları arasında anlamlı bir farklılık olup olmadığını araştırmak maksatıyla, " $H_{4}$ : Katılımcıların yıllık tatil sıklığı özelliklerine göre turizm tutumları arasında anlamlı farkııık vardır." araştırma hipotezi test edilmiştir.

\subsection{Veri Toplama Aracı}

Araştırmada kullanılan anket, iki bölümden oluşmaktadır. Illk bölümde, ankete katılan katılımcılara yönelik 7 adet demografik ve sosyo-ekonomik soru yer almaktadır. Anketin ikinci bölümünde ise katılımcıların turizme karşı tutumlarının belirlenmesine yönelik 22 adet soruya yer verilmiştir. Bu bölümde kullanılan anket soruları, temelini Lankford ve Howard 'ın (1994) attığı ve Wang ve diğ. (2006) tarafından geliştirilen, geçerlilik ve güvenirliği uluslararası ve ulusal yazında kanıtlanmış Turizm Etkileri Tutumu Ölçeğinden (TIAS) çevrilmiştir (Lankford ve Howard, 1994; Akova, 2006; Wang ve diğ., 2006; Assante ve diğ., 2014; Platania ve Santisi, 2016). Soruların anlaşılırlığı, kelime ve cümle yapıları kontrol edildikten sonra uzmanlardan alınan görüşler doğrultusunda gerekli düzenlemeler yapılarak, ölçeğe son hali verilmiştir. Tüm ölçüm araçlarında, beş maddeli Likert tipi (1-Kesinlikle Katılmıyorum, 2-Katılmıyorum, 3-Ne Katılıyorum Ne Katılmıyorum, 4-Katılıyorum ve 5-Kesinlikle Katılıyorum) ölçek kullanılmıştır.

\section{2. Ölçeğe İlişkin Geçerlilik ve Güvenilirlik Analizleri}

Bu çalışmada kullanılan ölçeğin geçerliliğinin test edilmesi amacıyla, yapı (construct) geçerliliği analizi içerisinde değerlendirilen, açıklayıcı (exploratory) faktör analizinden yararlanılmıştır. Faktör analizi, aynı yapıyı ya da niteliği ölçen değişkenleri bir araya toplayarak, ölçmeyi az sayıda faktör (boyut) ile açıklamayı amaçlayan bir istatistiksel tekniktir (Büyüköztürk, 2011). Bir ölçeğe ait geçerliliğin faktör analizi ile belirlenmesi için, o ölçüme ait veri setinin faktör analizi yöntemine uygun olması gerekmektedir. Verilerin açıklayıcı faktör analizine uygunluğu, Kaiser-Meyer-Olkin (KMO) Katsayısı ve Barlett Küresellik Testi ile incelenebilir. Faktörleşebilirlik için KMO katsayısının 0,6'dan büyük olması ve Barlett Küresellik Testi analizi kapsamında hesaplanan ki-kare istatistiğinin ise anlamlı çıkması beklenmektedir (Büyüköztürk, 2011). Yapılan analizler sonucunda bu çalışma için KMO katsayısı 0,710 olarak ölçülmüş, Bartlett Küresellik Testi anlamlılık değeri ise $p<, 000$ düzeyinde anlamlı bulunmuştur. Bulunan her iki değer, çalışmada kullanılan ölçeğin, faktör analizi için uygun olduğunu göstermektedir.

Faktör analizinde, faktörler altında kümeleşen her bir ifadeye ait faktör yük değerinin 0,45 ya da daha yüksek olması, seçim için iyi bir ölçüdür (Büyüköztürk, 2011). Dolayısıyla bu çalışma kapsamında yapılan açıklayıcı faktör analizinde faktör yükü alt sınırı 0,45 seçilmiş ve faktör yükü 0,45 'in altında kalan üç ifade analizden çıkartılmıştır. Geriye kalan 18 ifade Direct Oblimin döndürme yöntemi ile tekrar açıklayıcı faktör analizine tabi tutulmuş ve öz değeri birden büyük üç faktör elde 
edilmiştir. Analizde eğik (oblique) döndürme yönteminin tercih edilmesinin sebebi, faktörler arasında bir ilişki olduğu düşüncesidir. Analiz sonucunda açıklayıcı faktör analizine ilişkin her bir faktöre ait ifadelerin faktör yükleri ve her bir faktörün varyans açıklama oranı Tablo 1'de gösterilmiştir. Elde edilen üç faktörün toplam varyans açıklama oranı \%53,266 'dır. Bu değer, açıklayıcı faktör analizi için kabul edilebilir bir değerdir (Habing, 2003). Analiz sonucunda elde edilen birinci faktör "imkânlar" ile ilgili ifadeleri kapsamakta olup, toplam varyansın \%25,976'sını açıklamaktadır. İkinci faktör "teşvik ve etkiler" ile ilgili ifadeleri kapsamakta olup, toplam varyansın \%15,625ini açıklamaktadır. Üçüncü ve son faktör "yaşam şartları" ile ilgili ifadeleri kapsamakta olup, toplam varyansın \%11,625 ini açıklamaktadır.

\section{Tablo 1: Açıklayıcı Faktör Analizi Sonuçları}

\begin{tabular}{|c|c|c|c|}
\hline Boyutlar & Ölçek Ifadeleri & $\begin{array}{l}\text { Faktör } \\
\text { Yükü }\end{array}$ & $\begin{array}{l}\text { Varyans } \\
\text { Oranı }\end{array}$ \\
\hline İmkânlar & $\begin{array}{l}\text { Turizm sektörü, bulunduğum bölgede arzulanan istihdam } \\
\text { olanaklarını sağlamaktadır. }\end{array}$ & 913 & 25,976 \\
\hline$\alpha=0,876$ & $\begin{array}{l}\text { Turistik tesisler sayesinde bulunduğum bölgenin yaşam kalitesi } \\
\text { artmıştır. }\end{array}$ & ,858 & \\
\hline & $\begin{array}{l}\text { Bulunduğum bölgede turizm sayesinden daha fazla turistik etkinlik } \\
\text { olanaklarına sahibim. }\end{array}$ & ,834 & \\
\hline & $\begin{array}{l}\text { Turizmin bir sonucu olarak bulunduğum bölgede daha fazla } \\
\text { alışveriş yapma imkânına sahibim. }\end{array}$ & ,753 & \\
\hline & Turizm sayesinde bulunduğum bölgede daha iyi yollara sahibim. & ,746 & \\
\hline & $\begin{array}{l}\text { Bulunduğum bölgedeki kamu hizmetlerinin kalitesi, turizm } \\
\text { neticesinde iyileştirilmiştir. }\end{array}$ &, 578 & \\
\hline Teşvik ve Etkiler & $\begin{array}{l}\text { Bulunduğum bölgenin daha fazla turizm merkezi olması } \\
\text { gerektiğine inanıyorum. }\end{array}$ & ,733 & 15,625 \\
\hline$\alpha=0,749$ & Turizmi destekliyorum. & 691 & \\
\hline & Devletin turizmi desteklemesi doğru bir karardır. & 681 & \\
\hline & Turizmin olumlu etkileri olumsuz etkilerinden daha fazladır. & 654 & \\
\hline & $\begin{array}{l}\text { Turizmin, bulunduğum bölgede aktif olarak teşvik edilmesi } \\
\text { gerektiğine inanıyorum. }\end{array}$ & ,645 & \\
\hline & $\begin{array}{l}\text { Giresun'da turizmin daha fazla teşvik edilmesi gerektiğine } \\
\text { inanıyorum. }\end{array}$ &, 541 & \\
\hline & $\begin{array}{l}\text { Yerel yönetimlerin uzun dönem planlamaları neticesinde, turizmin } \\
\text { olumsuz etkileri kontrol altına alınabilir. }\end{array}$ & ,493 & \\
\hline Yaşam Şartları & $\begin{array}{l}\begin{array}{l}\text { Bulunduğum bölgede turistlerin yapmış olduğu harcamalardan } \\
\text { dolayı yaşam şartları zordur. }\end{array} \\
\end{array}$ & ,802 & 11,625 \\
\hline$\alpha=0,657$ & $\begin{array}{l}\text { Turizmin en önemli faydalarından birisi, yerel halkın yaşam } \\
\text { standartlarını yükseltmesidir. }\end{array}$ & 674 & \\
\hline & $\begin{array}{l}\text { Turizm, bulunduğum bölgede yapılmakta olan açık alan } \\
\text { faaliyetlerinin kalitesini düşürdü. * }\end{array}$ & ,646 & \\
\hline & $\begin{array}{l}\text { Turist akınları, bulunduğum bölgedeki turizm faaliyetlerini } \\
\text { genişletmiştir. }\end{array}$ & ,460 & \\
\hline & $\begin{array}{l}\text { Turizm sektörü, bulunduğum bölgenin ekonomisi için önemli rol } \\
\text { oynamaya devam edecektir. }\end{array}$ & ,458 & \\
\hline
\end{tabular}

Toplam Varyans Açıklama Oranı (\%):\%53,266,

KMO: 0,710, Bartlett Küresellik Testi: $P=, 000$

*=ifadeler ters kodlanmıştır

Güvenilirlik, ölçülerin hatadan bağımsız kalma dereceleridir. Alanyazında ölçek güvenilirliğiyle ilgili en yaygın kullanılan kıstas, Cronbach's Alpha iç tutarlılık değeridir. Cronbach's Alpha iç tutarlılık değeri 0 ile 1 arasında değer almaktadır ve değerler 1'e yaklaştıkça tutarlılık/güvenilirlik artmaktadır (Cronbach, 1990). Yapılan güvenilirlik analizi sonucunda, bu çalışmada kullanılan, turizm etkileri tutumu ölçeğinin Cronbach's Alpha iç tutarlılık değeri, 0,774 olarak bulunmuştur. Bulunan bu değer, bir bütün olarak ölçeğin güvenilir olduğunu göstermektedir. Çalışma kapsamında ayrıca, turizm etkileri tutumu ölçeğini oluşturan her bir faktörün, Cronbach's Alpha iç tutarlılık değeri de analiz edilmiştir. Ölçeği oluşturan her bir boyuta ait Cronbach's Alpha iç tutarlılık 
değerleri, Tablo.1'de gösterildiği üzere 0.876 ile 0,657 arasında değişmekte olup, bulunan bu değerler ölçeğin güvenilir olduğunu göstermektedir (Pallant, 2001).

\section{Araştırma Bulguları}

Çalışmada belirlenen araştırma hipotezlerinin testleri kapsamında, araştırmaya katılan Yavuzkemal belde merkezinde yaşayan yerel halkın \%51,1'i (67) erkek ve \%48,9'u (64) kadındır. Ayrıca \%39,7si (52) 26-30 yaş aralığında iken \%33,6’sı (44) 25 yaş ve altındadır. Katılımcıların \%53,4'ü (70) evli ve \%40,5i (53) bekârdır. Meslek dağılımlarına bakıldığında en yüksek oran \%31,3 (41) ile kamu sektörüne aittir. Bu değeri \%27,5 ile (36) çiftçiler takip etmektedir. Eğitim seviyesi bakımından katılımcıların \%59,5 ini (78) üniversite ve daha yüksek bir eğitim mezunları oluştururken, \%40,5 ini (53) ise lise ve daha düşük eğitim seviyesine sahip katılımcılar oluşturmaktadır. Aylık gelir bakımından katılımcıların yüzde dağılımı incelendiğinde, $\% 63,9$ 'unun (76) 2000 TL ve altında, \%36, 1'inin (43) ise 2000 TL ve üstünde geliri vardır. Son olarak katılımcıların yıllık seyahat sıklığı incelendiğinde, \%52,7 sinin (69) ya hiç seyahate çıkmamakta ya da en fazla bir kere seyahate çıkmaktadır.

Araştırmaya katılan Giresun ili Yavuzkemal belde merkezi yerel halkının, demografik ve sosyo-ekonomik bilgilerine ilişkin frekans ve yüzde dağılımlarından sonra, katılımcılara yöneltilen Turizm Etkileri Tutumu Ölçeği ifadeleri de analiz edilmiştir. Bu amaç ile yapılan betimleyici analiz sonuçları, Tablo.2'de gösterilmiştir.

Tablo 2: Turizm Etkileri Tutumu Ölçeği Betimleyici Analiz Sonuçları

\begin{tabular}{|c|c|c|c|}
\hline \multicolumn{4}{|l|}{ ifadeler } \\
\hline & $\mathbf{N}$ & Ort. & S.S. \\
\hline Turizmin, bulunduğum bölgede aktif olarak teşvik edilmesi gerektiğine inanıyorum. & 130 & 3,80 & ,772 \\
\hline Turizmi destekliyorum. & 130 & 3,83 & 695 \\
\hline $\begin{array}{l}\text { Turizmin, bulunduğum bölge açısından toplumun önemli bir parçası haline geldiğini } \\
\text { görmek istiyorum. }\end{array}$ & 130 & 3,68 & ,780 \\
\hline $\begin{array}{l}\text { Bulunduğum bölgede daha fazla turist çekecek, yeni turizm tesislerinin açılmasına } \\
\text { karşıyım. }\end{array}$ & 130 & 2,05 & ,879 \\
\hline Giresun'da turizmin daha fazla teşvik edilmesi gerektiğine inanıyorum. & 131 & 3,42 &, 868 \\
\hline Devletin turizmi desteklemesi doğru bir karardır. & 130 & 3,75 &, 761 \\
\hline Turizmin olumlu etkileri olumsuz etkilerinden daha fazladır. & 130 & 3,67 & ,686 \\
\hline Bulunduğum bölgenin daha fazla turizm merkezi olması gerektiğine inanıyorum. & 131 & 3,68 & ,757 \\
\hline $\begin{array}{l}\text { Yerel yönetimlerin uzun dönem planlamaları neticesinde, turizmin olumsuz etkileri } \\
\text { kontrol altına alınabilir. }\end{array}$ & 130 & 3,70 & ,743 \\
\hline $\begin{array}{l}\text { Turizm, bulunduğum bölgede yapılmakta olan açık alan faaliyetlerinin kalitesini } \\
\text { düşürdü. }\end{array}$ & 128 & 3,04 & 1,023 \\
\hline Turizmin gelişimini yönetebilmek için planlar geliştirmek önemlidir. & 131 & 3,52 &, 889 \\
\hline $\begin{array}{l}\text { Turizm sektörü, bulunduğum bölgenin ekonomisi için önemli rol oynamaya devam } \\
\text { edecektir. }\end{array}$ & 131 & 3,53 & ,747 \\
\hline $\begin{array}{l}\text { Turizmin en önemli faydalarından birisi, yerel halkın yaşam standartlarını } \\
\text { yükseltmesidir. }\end{array}$ & 131 & 3,36 & ,823 \\
\hline $\begin{array}{l}\text { Bulunduğum bölgede turistlerin yapmış olduğu harcamalardan dolayı yaşam şartları } \\
\text { zordur. }\end{array}$ & 131 & 2,88 & ,977 \\
\hline Turist akınları, bulunduğum bölgedeki turizm faaliyetlerini genişletmiştir. & 128 & 3,04 &, 891 \\
\hline Bulunduğum bölgedeki kamu hizmetlerinin kalitesi, turizm neticesinde iyileştirilmiştir. & 130 & 3,28 & ,837 \\
\hline $\begin{array}{l}\text { Bulunduğum bölgede turizm sayesinden daha fazla turistik etkinlik olanaklarına } \\
\text { sahibim. }\end{array}$ & 131 & 3,33 & ,872 \\
\hline Turistik tesisler sayesinde bulunduğum bölgenin yaşam kalitesi artmıştır. & 130 & 3,51 & ,828 \\
\hline Turizm sektörü, bulunduğum bölgede arzulanan istihdam olanaklarını sağlamaktadır. & 131 & 3,51 & ,923 \\
\hline Turizm sayesinde bulunduğum bölgede daha iyi yollara sahibim. & 130 & 3,66 & ,868 \\
\hline $\begin{array}{l}\text { Turizmin bir sonucu olarak bulunduğum bölgede daha fazla alışveriş yapma } \\
\text { imkânına sahibim. }\end{array}$ & 131 & 3,68 & ,922 \\
\hline
\end{tabular}


Tablo 2'de verilen betimleyici analiz sonuçları incelendiğinde, en yüksek ortalamaya sahip ifadenin, "Turizmi destekliyorum." ifadesi olduğu görülmektedir (Ort.=3,83). Bu ifadeyi, "Turizmin, bulunduğum bölgede aktif olarak teşvik edilmesi gerektiğine inanıyorum." ifadesi takip etmektedir (Ort.=3,80). Betimleyici analiz sonuçlarına göre en düşük ortalamaya sahip ifadenin ise, "Bulunduğum bölgede daha fazla turist çekecek, yeni turizm tesislerinin açılmasına karşıyım." ifadesi olduğu görülmektedir (Ort.=2,05). Bu ifadeyi, "Bulunduğum bölgede turistlerin yapmış olduğu harcamalardan dolayı yaşam şartları zordur." ifadesi takip etmektedir (Ort.=2,88).

Çalışmada verilen birinci araştırma hipotezinin testi için, çoklu regresyon analizinden yararlanılmıştır. Bu analiz öncesinde çalışmada verilen tüm regresyon modelleri için bağımsız değişkenler arasında bulunan çoklu doğrusal bağlantı (multicollinearity) sorunu, otokorelasyon sorunu ve normallik varsayımları araştırılmış ve sonuçlar Tablo 3'de gösterilmiştir. Çoklu bağlantı sorunu için varyans büyütme faktörleri (VIF) ve tolerans değerleri incelenmiş ve verilen tüm regresyon modelleri için bağımsız değişkenlere ait VIF değerlerinin 10'dan küçük ve tolerans değerlerinin 0,10'dan büyük olduğu görülmüştür. Bulunan bu değerler, bağımsız değişkenler arasında çoklu bağlantı sorunu olmadığının bir göstergesidir (Hair ve diğ., 2006). Regresyon modellerinin otokorelasyon sorunu testi için Durbin-Watson istatistiğinden yararlanılmıştır. Analiz sonucunda, regresyon modelleri için bu değerlerin 1,768 ve 1,690 olarak istenilen değerler $(1,5 / 2,5)$ arasında olduğu görülmüştür (Hair ve diğ., 2006). Bulunan bu değerler, verilen regresyon modelleri için otokorelasyon sorunu olmadığının bir kanıtıdır. Son olarak verilen regresyon modelleri, Residual Plots yardımı ile analiz edilmiş ve elde edilen diyagramlar incelendiğinde, bağımlı değişkenlerin beklenen desenle uyumlu olduğu görülmüştür. Bu durum, regresyon modellerine iliş̧in veri setinin normal dağılıma uygun olduğunu göstermektedir (Seltman, 2015). Birinci araştırma hipotezinin test edilmesi kapsamında öncelikle, ölçek boyutları analiz edilmek istenmiştir. Bu amaç ile Turizm Etkileri Tutumu Ölçeği boyutları bağımsız değişken ve katılımcılara yöneltilen "Yeşil Yol Projesi ile birlikte Yavuzkemal beldesinin turizm olanakları daha fazla gelişecektir." ifadesi bağımlı değişken olarak ele alınmış ve yapılan çoklu regresyon analizi sonuçları Tablo 3'de gösterilmiştir.

Tablo 3: Regresyon Analizi Sonuçları

\begin{tabular}{|l|c|c|c|c|c|}
\hline Faktörler & $\boldsymbol{\beta}$ Katsayısı & $\boldsymbol{t}$-değeri & $\boldsymbol{p}$ & Tolerans & VIF \\
\hline (Sabit Değer) &, 241 & 0,363 & 0,717 & & \\
\hline Imkânlar &, 546 & 6,855 &, $000^{* *}$ &, 881 & 1,134 \\
\hline Teşvik ve Etkiler &, 101 & 1,348 & 0,180 &, 995 & 1,005 \\
\hline Yaşam Şartları &, 093 & 1,167 & 0,246 &, 885 & 1,130 \\
\hline$R^{2}=, 358$ F=21,367 p=,000 Durbin-Watson=1,768 & & & & & \\
\hline${ }^{* *}$ p<0,01 & & & & & \\
\hline Imkânlar Boyutu Ifadeleri & & & & & \\
\hline (Sabit Değer) &, 872 & 2,826 &, $006^{* *}$ & & \\
\hline $\begin{array}{l}\text { Turizmin bir sonucu olarak bulunduğum bölgede } \\
\text { daha fazla alışveriş yapma imkânına sahibim }\end{array}$ &, 373 & 3,679 &, $000^{* *}$ &, 426 & 2,349 \\
\hline $\begin{array}{l}\text { Turizm sayesinde bulunduğum bölgede daha iyi } \\
\text { yollara sahibim. }\end{array}$ &, 368 & 3,683 &, $000^{* *}$ &, 446 & 2,244 \\
\hline $\begin{array}{l}\text { Bulunduğum bölgedeki kamu hizmetlerinin kalitesi, } \\
\text { turizm neticesinde iyileştirilmiştir }\end{array}$ &, 313 & 3,433 &, $001^{* *}$ &, 495 & 2,019 \\
\hline $\begin{array}{l}\text { Bulunduğum bölgede turizm sayesinden daha fazla } \\
\text { turistik etkinlik olanaklarına sahibim. }\end{array}$ &, 270 & 3,185 &, $002^{* *}$ &, 439 & 2,278 \\
\hline \multicolumn{2}{|l|}{$R^{2}=, 520$ F=21,890 p=,000 Durbin-Watson=1,690 } & & & & **p<0,01
\end{tabular}

$\mathrm{Bu}$ amaç ile gerçekleştirilen regresyon modeli anlamlıdır $(F=21,367, p=, 000)$. Tabloda bulunan standardize edilmiş $\beta$ katsayıları incelendiğinde, imkanlar boyutunun, katılımcıların Yeşil Yol Projesi'ne yönelik algılarını $\beta=, 546$ düzeyinde etkilediği 
görülmektedir. Başka bir ifade ile katılımcılar, Yeşil Yol Projesi'ne karşı algılarını belirtirken, \%54,6 oranında İmkânlar boyutu ifadelerinin etkisi altında kalmaktadır. Verilen diğer iki boyutun modele katkısı anlamlı bulunamamıştır. Bu sonuçlardan sonra, Turizm Etkileri Tutumu Ölçeğinin imkanlar boyutunu oluşturan ifadelere yönelik ikinci bir analizin, ortaya çıkan bu etkiyi daha detaylı olarak açıklayacağı öngörülmüş ve bu amaç ile imkanlar boyununu oluşturan ifadeler bağımsız değişken olarak ele alınarak analiz tekrarlanmıştır. Analiz sonucunda, regresyon modeline ( $F=21,890$, $p=, 000)$ katkısı anlamlı bulunan ifadeler, Tablo.3'de gösterilmiştir. Tabloda verilen standardize edilmiş $\beta$ katsayıları incelendiğinde, "Turizmin bir sonucu olarak bulunduğum bölgede daha fazla alışveriş yapma imkânına sahibim." ifadesinin, katılımcıların Yeşil Yol Projesi'ne yönelik algılarını belirtirken, $\beta=, 373$ düzeyi ile etkisi altında kaldıkları en önemli ifade olduğu görülmüştür. $\beta=, 368$ düzeyi ile "Turizm sayesinde bulunduğum bölgede daha iyi yollara sahibim." ifadesi, katılımcıların algılarını etkileyen ikinci önemli ifadedir. Bu ifadeleri, önem/etki sırasına göre, "Bulunduğum bölgedeki kamu hizmetlerinin kalitesi, turizm neticesinde iyileştirilmiştir." ve "Bulunduğum bölgede turizm sayesinden daha fazla turistik etkinlik olanaklarına sahibim." ifadeleri takip etmektedir. Yapılan regresyon analizleri neticesinde, " $H_{1}$ : Katılımcıların Yavuzkemal beldesine yönelik mevcut turizm tutumları, Yeşil Yol Projesi'ne karşı algılarını etkilemektedir." hipotezi kabul edilmiştir.

Çalışma kapsamında verilen ikinci araştırma hipotezinin testi için, Bağımsız (İlişkisiz) Örneklem T-Testi analizinden yararlanılmıştır. Analiz öncesinde verilerin parametrik testler için uygunluğu kontrol edilmiştir. Bu amaç ile normallik varsayımı araştırılmış ve her iki eğitim grubu için veri setinin çarpıklık (skewness) ve basıklık (kurtosis) değerlerinin istenilen değerler $(+1,5 /-1,5)$ arasında yer aldığı, yani veri setinin normal dağılım gösterdiği tespit edilmiştir (Tabachnick ve Fidell, 2013). Yapılan Bağımsız Örneklem T-Testi analizi sonucunda, katıımcıların eğitim düzeyi özellikleri bakımından aralarında anlamlı farklılık bulunan ifadeler, Tablo.4'de gösterilmiştir.

Tablo 4: Eğitim Düzeyine Göre Bağımsız Örneklem T-Testi Analizi Sonuçları

\begin{tabular}{|l|c|c|c|c|c|}
\hline \multirow{2}{*}{ Ifadeler } & \multicolumn{2}{|c|}{$\begin{array}{c}\text { Lise ve Daha } \\
\text { Düşük }\end{array}$} & \multicolumn{2}{c|}{$\begin{array}{c}\text { Unniversite ve } \\
\text { Daha Yüksek }\end{array}$} & \multirow{2}{*}{$p$} \\
\cline { 2 - 4 } & Ort. & S.S. & Ort. & S.S. \\
\hline $\begin{array}{l}\text { Turizmin, bulunduğum bölgede aktif olarak teşvik edilmesi } \\
\text { gerektiğine inanıyorum. }\end{array}$ & 3,63 &, 742 & 3,91 &, 776 &, $046^{*}$ \\
\hline $\begin{array}{l}\text { Turizmin, bulunduğum bölge açısından toplumun önemli bir } \\
\text { parçası haline geldiğini görmek istiyorum. }\end{array}$ & 3,40 &, 846 & 3,86 &, 679 &, $001^{* *}$ \\
\hline $\begin{array}{l}\text { Turizm sektörü, bulunduğum bölgenin ekonomisi için önemli } \\
\text { rol oynamaya devam edecektir. }\end{array}$ & 3,38 &, 713 & 3,64 &, 755 &, $047^{*}$ \\
\hline
\end{tabular}

Tablo.4 incelendiğinde, verilen üç ifade için, katılımcıların eğitim düzeyi özelliklerine göre, gruplar arasında anlamlı farklılıklar bulunduğu gözlemlenmiştir. Verilen tüm ifadelerde, eğitim seviyesi üniversite ve daha yüksek olan katılımcıların algıları, eğitim seviyesi lise ve daha düşük olan katılımcıların algılarından yüksek olduğu görülmektedir. Verilen bu üç ifadenin dışında kalan ifadelerde, katılımcıların eğitim düzeyleri özelliklerine göre turizme yönelik tutumları arasında anlamlı farklılık bulunamamıştır. Analiz sonucuna göre, verilen " $\mathrm{H}_{2}$ : Katılımcıların eğitim düzeyi özelliklerine göre turizm tutumları arasında anlamlı farklılı vardır." hipotezi kabul edilmiştir.

Benzer şekilde, çalışma kapsamında verilen üçüncü araştırma hipotezinin testi için, Bağımsız Örneklem T-Testi analizinden yararlanılmıştır. Veri setinin bu analiz için uygunluğunu test etmek amacıyla yapılan normallik analizi sonucunda, veri setinin her 
iki gelir grubunda normal dağılım gösterdiği tespit edilmiştir (Tabachnick ve Fidell, 2013). Yapılan Bağımsız Örneklem T-Testi analizi sonucunda, katıımcıların gelir düzeyi özellikleri bakımından aralarında anlamlı farklılık bulunan ifadeler, Tablo.5'de gösterilmiştir.

\section{Tablo 5: Gelir Düzeyine Göre Bağımsız Örneklem T-Testi Analizi Sonuçları}

\begin{tabular}{|c|c|c|c|c|c|}
\hline \multirow[t]{2}{*}{ ifadeler } & \multicolumn{2}{|c|}{$\begin{array}{c}2000 \text { TL ve } \\
\text { Altı }\end{array}$} & \multicolumn{2}{|c|}{$\begin{array}{l}2000 T L v e \\
\text { Üstü }\end{array}$} & \multirow[t]{2}{*}{$p$} \\
\hline & Ort. & S.S. & Ort. & S.S. & \\
\hline $\begin{array}{l}\text { Turizmin, bulunduğum bölgede aktif olarak teşvik edilmesi } \\
\text { gerektiğine inanıyorum. }\end{array}$ & 3,68 & 756 & 4,02 &, 771 &, $020^{*}$ \\
\hline $\begin{array}{l}\text { Turizmin, bulunduğum bölge açısından toplumun önemli bir parçası } \\
\text { haline geldiğini görmek istiyorum. }\end{array}$ & 3,52 & 795 & 3,95 & ,615 &, $003^{* \star}$ \\
\hline $\begin{array}{l}\text { Turizmin bir sonucu olarak bulunduğum bölgede daha fazla alışveriş } \\
\text { yapma imkânına sahibim. }\end{array}$ & 3,87 & 754 & 3,40 & 1,003 & 0 \\
\hline
\end{tabular}

Tablo.5 incelendiğinde, verilen üç ifade için, katılımcıların gelir düzeyi özelliklerine göre, gruplar arasında anlamlı farklılıklar tespit edilmiştir. Verilen ilk iki ifadede, gelir seviyesi 2000 TL ve üstü olan katılımcıların algılarının, gelir seviyesi 2000 TL ve altında olan katılımcıların alglarından yüksek olduğu sonucuna ulaşılmıştır. Ancak verilen son ifadede, gelir seviyesi 2000 TL ve altında olan katılımcıların algıları, gelir seviyesi 2000 TL ve üstünde olan katılımcıların algılarından yüksektir. Geri kalan ifadelerde, katılımcıların gelir düzeyi özelliklerine göre turizme yönelik tutumları arasında anlamlı farklılık bulunamamıştır. Analiz sonucuna göre, verilen " $H_{3}$ : Katılımcıların aylık gelir düzeyi özelliklerine göre turizm tutumları arasında anlamlı farkııık vardır." hipotezi kabul edilmiştir.

Tablo 6: Tatil Sıklığına Göre Tek Yönlü Varyans Analizi Sonuçları

\begin{tabular}{|c|c|c|c|c|c|c|c|c|}
\hline \multirow[t]{2}{*}{ Ífadeler } & \multicolumn{2}{|c|}{$\begin{array}{c}0-1 \\
\text { Kere }\end{array}$} & \multicolumn{2}{|c|}{$\begin{array}{l}2-3 \\
\text { Kere }\end{array}$} & \multicolumn{2}{|c|}{$\begin{array}{l}4 \text { ve } \\
\text { Üzeri }\end{array}$} & \multirow[t]{2}{*}{$F$} & \multirow[t]{2}{*}{$p$} \\
\hline & Ort. & S.S. & Ort. & S.S. & Ort. & S.S. & & \\
\hline $\begin{array}{l}\text { Turizmin, bulunduğum bölge açısından toplumun } \\
\text { önemli bir parçası haline geldiğini görmek } \\
\text { istiyorum. }\end{array}$ & 3,53 & ,782 & 3,70 & ,915 & 3,97 & ,538 & 3,612 &, $030 *$ \\
\hline $\begin{array}{l}\text { Bulunduğum bölgede turistlerin yapmış olduğu } \\
\text { harcamalardan dolayı yaşam şartları zordur. }\end{array}$ & 2,75 & ,914 & 2,77 & 1,04 & 3,25 & ,984 & 3,178 &, $045^{*}$ \\
\hline $\begin{array}{l}\text { Turist akınları, bulunduğum bölgedeki turizm } \\
\text { faaliyetlerini genişletmiştir. }\end{array}$ & 3,09 & ,859 & 2,70 & ,837 & 3,27 & ,944 & 3,377 &, $037^{*}$ \\
\hline $\begin{array}{l}\text { Bulunduğum bölgedeki kamu hizmetlerinin } \\
\text { kalitesi, turizm neticesinde iyileştirilmiştir. }\end{array}$ & 3,31 & ,778 & 2,90 & ,845 & 3,59 & ,837 & 5,770 &, $004^{\star \star}$ \\
\hline $\begin{array}{l}\text { Bulunduğum bölgede turizm sayesinden daha } \\
\text { fazla turistik etkinlik olanaklarına sahibim. }\end{array}$ & 3,32 & ,795 & 3,00 & ,910 & 3,66 & ,902 & 4,638 &, $011^{*}$ \\
\hline $\begin{array}{l}\text { Turistik tesisler sayesinde bulunduğum bölgenin } \\
\text { yaşam kalitesi artmıştır. }\end{array}$ & 3,47 & ,782 & 3,23 & ,935 & 3,84 & ,723 & 4,590 &, $012^{*}$ \\
\hline $\begin{array}{l}\text { Turizm sektörü, bulunduğum bölgede arzulanan } \\
\text { istihdam olanaklarını sağlamaktadır. }\end{array}$ & 3,51 & ,816 & 3,20 & 1,157 & 3,81 & ,821 & 3,545 &, $032^{*}$ \\
\hline $\begin{array}{l}\text { Turizm sayesinde bulunduğum bölgede daha iyi } \\
\text { yollara sahibim. }\end{array}$ & 3,66 & ,908 & 3,27 & ,868 & 4,03 & ,595 & 6,527 &, $002^{* *}$ \\
\hline $\begin{array}{l}\text { Turizmin bir sonucu olarak bulunduğum bölgede } \\
\text { daha fazla alısveriş yapma imkânına sahibim. }\end{array}$ & 3,64 & ,985 & 3,37 & ,850 & 4,06 & ,716 & 4,826 &, $010^{*}$ \\
\hline
\end{tabular}

Çalışma kapsamında verilen son araştırma hipotezinin testi için, Tek Yönlü Varyans (Anova) analizinden yararlanılmıştır. Analiz öncesinde veri setinin bu analiz için uygunluğu test edilmiştir. İlk olarak normallik varsayımı araştırılmış ve verilerin her bir tatil sıklığı grubunda normal dağılıma sahip olduğu gözlemlenmiştir (Tabachnick ve 
Fidell, 2013). Ardından homojenlik varsayımı araştırılmış ve Levene İstatistiği sonucuna göre her bir tatil sıklığı grubu varyansının homojen olduğu sonucuna ulaşılmıştır. Yapılan Tek Yönlü Varyans analizi sonucunda, katılımcıların tatil sıklığı özellikleri bakımından aralarında anlamlı farklılık bulunan ifadeler, Tablo.6'da gösterilmiştir.

Bütün ifadeler için grupların varyansı homojen dağılım gösterdiğinden, farkların hangi yıllık seyahat sıklığı grubundan kaynaklandığını bulmak maksadıyla Scheffe testinden faydalanılmıştır. Test sonuçlarına göre verilen ilk iki ifadede, yıllık seyahat sıklığı 0-1 kere olan katılımcıların algıları ile yıllık seyahat sıklığı 4 ve üzerinde olan katılımcıların algıları arasında $p<0,05$ düzeyinde anlamlı farklılıklar bulunmuştur. Bu iki ifade için, yıllık seyahat sıklığı 4 ve üzerinde olan katılımcılarının algılarının daha yüksek olduğu görülmektedir. Geri kalan tüm ifadelerde, yıllık seyahat sıklığı 2-3 kere olan katılımcıların algıları ile yıllık seyahat sıklığı 4 ve üzerinde olan katılımcıların algıları, $p<0,01$ ve $p<0,05$ düzeylerinde anlamlı derecede farklılaşmaktadır. Bu ifadeler için de yıllık seyahat sıklığı 4 ve üzerinde olan katılımcıların algılarının daha olumlu olduğu dikkat çekmektedir. Dokuz ifadenin dışında kalan ifadelerde, katılımcıların yıllık seyahat sıklığı özelliklerine göre, turizm tutumları arasında anlamlı bir farklılık gözlemlenmemiştir. Analiz sonucuna göre, verilen " $H_{4}$ : Katılımcıların yıllık tatil sıklığı özelliklerine göre turizm tutumları arasında anlamlı farklılı vardır." hipotezi kabul edilmiştir.

\section{Sonuç ve Tartışma}

Bu çalışmanın öncelikli amacı olarak, Yavuzkemal belde merkezinde yaşayan yerel halkın mevcut turizm tutumlarının, Yeşil Yol Projesi'ne yönelik algıları üzerindeki etkisi araştırılmıştır. Bu amaç ile gerçekleştirilen regresyon analizinde öncelikle, Turizm Etkileri Tutumu Ölçeği boyutları incelenmiş ve yapılan analiz sonucunda "imkanlar" boyutunun katılımcıların Yeşil Yol Projesi'ne karşı algılarını etkiyelen önemli bir boyut olduğu ortaya çıkmıştır (Tablo 3). Ortaya çıkan bu etkiyi daha detaylı açıklamak adına imkanlar boyutu ifadelerini kapsayarak yapılan ikinci bir analiz sonucunda, "Turizmin bir sonucu olarak bulunduğum bölgede daha fazla alışveriş yapma imkânına sahibim." ifadesinin, katılımcıların Yeşil Yol Projesi'ne yönelik yargı belirtirken, etkisi altında kaldıkları en önemli ifade olduğu görülmüştür. Bu sonucun ortaya çıkmasında, Yavuzkemal belde merkezi yerel halkının, Yeşil Yol Projesi ile turistik ürün ve hizmetlere kavuşma isteği düşüncesinin etkili olduğu söylenebilir. Yavuzkemal beldesinde turistik amaçlı ürün ve hizmet satın alınabilecek bir işletme bulunmamaktadır. Bu tarz turistik ürün ve hizmet satan işletmelerin beldede bulunmayışı, katılımcıların gözünde bu projeye olan algı ve bakışı etkiliyor olabilir. Analiz sonucunda, "Turizm sayesinde bulunduğum bölgede daha iyi yollara sahibim." ifadesi, katılımcıların Yeşil Yol Projesi'ne karşı algılarını etkileyen bir diğer önemli ifade olarak göze çarpmaktadır. Proje ana amacının Doğu Karadeniz Bölgesi'nde bulunan yaylaları birbirine bağlaması öngörülen, doğu-batı yönlü bir ana ulaşım aksının devreye sokulması olduğu düşünülürse ortaya çıkan bu sonuç sürpriz olmayacaktır. Katılımcıların Yeşil Yol Projesi'ne karşı algılarını etkileyen bir diğer önemli ifade, "Bulunduğum bölgedeki kamu hizmetlerinin kalitesi, turizm neticesinde iyileştirilmiştir." ifadesidir. Bu durumu Yavuzkemal beldesinin mevcut kamu hizmetleri potansiyeli ile açıklamak mümkündür. Beldede henüz hizmet veren hastane ve lise bulunmamaktadır. Turizmin, kamu hizmetlerini artırıcı ve geliştirici etkileri düşünüldüğünde, proje kapsamında beldede henüz bulunmayan kamu hizmetleri eksikliğinin giderileceği ve mevcut kamu hizmetlerinin kalitesinin artıılacağı düşüncesi ile katılımcıların böyle bir ifadenin etkisi altında kalması, son derece muhtemeldir. Katılımcıların Yeşil Yol Projesi'ne yönelik algılarını etkileyen son ifade, "Bulunduğum bölgede turizm 
sayesinden daha fazla turistik etkinlik olanaklarına sahibim." ifadesidir. Yavuzkemal beldesinde yıl içerisinde çeşitli turistik etkinlikler düzenlenmektedir. Düzenlenen bu etkinlikler çok sayıda yerli ve yabancı turisti beldeye çekmektedir. Bu durum, beldede yaşamını sürdüren halk açısından gerek ekonomik gerekse sosyal açıdan kazanımlar sağlamaktadır. Yeşil Yol Projesi'nin, mevcut bölgesel turizm faaliyetlerini artıracağı ve turizmden elde edilen kazanımları çoğaltacağı düşüncesi, katılımcıların gözünde projeye olan algıyı olumlu şekilde etkilediği söylenebilir.

Çalışmanın bir diğer önemli amacı olarak, yerel halkın demografik ve sosyoekonomik özelliklerine göre bölgesel kalkınma açısından son derece önemli olan turizme karşı bakış açıları ve tutumları incelenmiştir. Bu amaçla öncelikle, katılımcıların eğitim düzeyi özelliklerine göre turizm tutumları arasında anlamlı bir farklılık olup olmadığını analiz edilmiştir. Analiz sonuçları neticesinde üç ifadede, katılımcıların eğitim düzeyi özelliklerine göre bölgesel turizm tutumlarında anlamlı farklılıklar tespit edilmiştir (Tablo 4). Aralarında anlamlı farklılık bulunan bütün ifadelerde, katılımcıların eğitim seviyesi arttıkça, bölgesel turizm faaliyetlerine yönelik tutumlarının da olumlu yönde değiştiği görülmüştür. Bu sonuç, alanyazında yapılan çalışmalar ile benzerlik göstermektedir (Kızılırmak ve Kurtuldu, 2005; Wang ve Pfister, 2008; İlban ve Bezirgan, 2011). Analiz sonuçlarına göre, üniversite ve daha üstü eğitim seviyesine sahip katılımcıların, turizmin bölgesel kalkınma açısından daha fazla teşvik edilmesi gerektiğine inandığı, bu sayede gelişmekte olan turizmden daha fazla fayda sağlamayı düşündüğü söylenebilir. Ayrıca bu katılımcılar için bulundukları bölge açısından turizmin daha fazla toplumun parçası haline geldiğini görmek istedikleri çıkarımı yapılabilir. Aynı şekilde üniversite ve daha üstü eğitim seviyesine sahip katılımcıların, bu çalışmada sıklıkla bahsedildiği üzere, turizmin bölgeler arasındaki ekonomik farklılıkları ortadan kaldıran önemli bir sektör olduğunun daha fazla bilincinde olduğu söylenebilir.

Çalışmada benzer şekilde, katılımcıların gelir düzeyi özelliklerine göre turizm tutumları arasında anlamlı bir farklılık olup olmadığını analiz edilmiştir. Analiz sonuçları, üç ifadede katılımcıların gelir düzeyi özelliklerine göre bölgesel turizm tutumları arasında anlamlı farklıııklar olduğunu ortaya çıkarmıştır (Tablo 5). Bu sonuç, alanyazında yapılan birçok çalışma ile örtüşmektedir (Akova, 2006; Okuyucu ve Somuncu, 2012; Szell ve Hallett, 2013). Analiz sonucunda, verilen ilk iki ifade için katılımcıların gelir seviyesi artarken, turizm tutumlarının da olumlu hale geldiği görülmektedir. Gelir düzeyi yüksek olan katılımcıların, serbest zamanlarında aktif olarak turizme daha sık katıldığı, bu durumun katılımcılarda turizm bilincini artırdığı söylenebilir. Artan turizm bilinci, katılımcıların bölgesel turizm faaliyetlerine yönelik algılarını yükseltmektedir. Bu çalışmaya katılan katılımcılar arasında, geçimini turistik değeri olan yerel işaretli ürünleri satarak sağlamaya çalışanlar da bulunmaktadır. Gelirin, Yavuzkemal beldesinde turizmin etkisiyle artması, başta geçimini bölgesel yerel işaretli ürün satarak sağlamaya çalışan katılımcıların algılarını olumlu olarak etkilemektedir. Bu durum beldede, turizmin daha fazla teşvik edilmesi gerekliliği algısını yaratmaktadır. Turizmin, gelişmekte olan bölgelere yönelik gelir artırıcı (ekonomik) fonksiyonları düşünüldüğünde, ortaya çıkan bu sonuç sürpriz olmayacaktır. Alanyazında yapılan birçok çalışma, bu çıkarımı desteklemektedir (Andereck ve Vogt, 2000; Wang ve Pfister, 2008; Woo ve diğ., 2016). Ayrıca bu çalışmaya katılan ve geliri 2000 TL ve altında olan katılımcıların büyük bir çoğunluğu $(\% 46,1)$ geçimini çiftçilik ile sağlamaktadır. Bu durum, ankete katılan ve geçimini çiftçilik ile sağlamaya çalışan katılımcıları, turizme karşı görece duyarsız hale getirmektedir. Ortaya çıkan bu duyarsızlığın, katılımcıların bölgesel turizm tutumlarını olumsuzlaştırdığı söylenebilir. Ancak tabloda verilen, "Turizmin bir sonucu olarak bulunduğum bölgede daha fazla alışveriş yapma imkânına sahibim.” ifadesinde, katılımcıların gelir seviyesi arttıkça, 
turizme yönelik algıları olumsuz yönde değişmektedir. Ortaya çıkan bu bulgu bir önceki bulgu ile çelişmektedir. Alanyazında benzer sonuçlara işaret eden çalışmalar da bulunmaktadır (Türker ve Türker, 2014). Bu çalışma için ortaya çıkan sonucu, Yavuzkemal beldesinin turizm amaçlı alışveriş potansiyeli ile açıklamak mümkündür. Beldede turizm amaçlı ürün satın alınabilecek bir işletme bulunmamaktadır. Turizm amacıyla harcanamayan gelir, katılımcıların bu yönde algısını olumsuz olarak etkilediği söylenebilir.

Çalışmada verilen son araştırma hipotezinin testi için gerçekleştirilen Tek Yönlü Varyans analizi sonuçları, dokuz ifadede katılımcıların yıllık seyahat sıklığı özelliklerine göre turizm tutumları arasında anlamlı farklılıklar olduğu sonucunu ortaya çıkarmıştır (Tablo.6). Analiz sonuçları incelendiğinde, verilen bütün ifadelerde, yıllık seyahat sıklığı sayısı 4 ve üzeri olan katılımcıların algıları, diğer grupların algılarından yüksektir. Alanyazında yapılan benzer çalışmalar, bu sonucu desteklemektedir (Kızılırmak ve Kurtuldu, 2005; İlban ve diğ., 2011). Ancak analiz sonucunda katılımcıların yıllık seyahat sıklığı özelliklerine göre bölgesel turizm faaliyetlerine yönelik algılarının sistematik bir şekilde artış göstermediği görülmektedir. Bir başka ifade ile yıllık seyahat sıklığı arttıkça, katılımcıların bölgesel turizm faaliyetlerine yönelik algılarının da olumlu yönde değişmesi beklenmektedir. Ortaya çıkan bu durumu, katılımcıların sosyoekonomik özellikleri ile açıklamak mümkündür. Bu çalışmaya katılan Yavuzkemal belde merkezi yerel halkının \%52,7 sinin, yıl içerisinde tatile çıkmadığı ya da en fazla bir kere tatile çıktığı görülmekledir. Bu durum, yıllık seyahat sıklığı 0-1 kere olan katılımcılar için, turizmin bölgesel gelişmişlik üzerine etkilerini yeteri kadar değerlendirememe ve analiz edememe endişesini doğurmaktadır.

Çalışmada ayrıca, Yavuzkemal belde merkezinde yaşayan yerel halka yöneltilen, "Yeşil Yol Projesi ile birlikte Yavuzkemal beldesinin turizm olanakları daha fazla gelişecektir." ifadesine yönelik yapılan betimleyici analiz sonucunda, katılımcıların \%57,3'ünün "Katılıyorum" ve \%22,9'unun "Kesinlikle katılıyorum" seçeneğini işaretlediği ve ifade ortalamasının 3,92 olduğu görülmüştür. Bu sonuç, Yavuzkemal belde merkezi yerel halkının, Yeşil Yol Projesi ile beldede bulunan mevcut turizm olanaklarının daha fazla gelişeceğine inandıklarını göstermektedir. Tüm bu bilgiler ışığında, Giresun ili Yavuzkemal belde merkezinde yaşayan yerel halkın gerek turizme gerekse Yeşil Yol Projesi'ne karşı algılarının olumlu olduğu görülmektedir. Ancak bu noktada önemli olan, alanyazında sıklıklar belirtildiği üzere (Butler, 1980; Lankford ve Howard, 1994; Wang ve Pfister, 2008), Yavuzkemal belde merkezi yerel halkının turizme ve Yeşil Yol Projesi'ne karşı tutumlarında zaman geçtikçe bir azalma/olumsuzluk olup olmayacağıdır. Ayrıca daha önce de belirtildiği gibi Yeşil Yol Projesi, zaman zaman proje yürütücüleri ve yerel halkı karşı karşıya getirmektedir. Bu sebeple, proje kapsamında geliştirilmesi öngörülen diğer turizm merkezlerinde yapılacak daha geniş katılımlı benzer çalışmalar, Yeşil Yol Projesi'ne yönelik ortaya çıkan bu negatif yaklaşımların sebebinin açıklanması ve/veya sonuçların karşılaştırılması açısından proje yürütücüleri ve araştırmacılara önemli bilgiler sunacaktır.

\section{Kaynakça}

Akova, O. (2006), 'Yerel Halkın Turizmin Etkilerini Algılamalarına ve Tutumlarına Yönelik Bir Araştırma', Akademik Incelemeler Dergisi, 2 (1), ss. 1-33.

Alaeddinoğlu, F. (2008), 'Sivas Kentinde Halkın Turiste ve Turizme Bakışı', Uluslararası Insan Bilimleri Dergisi, 5 (2), ss. 1-23. 
Andereck, K. L. ve Vogt, A. C. (2000), 'The Relationship between Residents' Attitudes toward Tourism and Tourism Development Options', Journal of Travel Research, 39 (1), ss. 27-36.

Arslan, K. (2005), 'Bölgesel Kalkınma Farklılıklarının Giderilmesinde Etkin Bir Araç: Bölgesel Planlama ve Bölgesel Kalkınma Ajansları', İstanbul Ticaret Üniversitesi Sosyal Bilimler Dergisi, 7 (1), ss. 275-294.

Assante, L. M., Wen, H. I., ve Lottig, K. (2014), 'An Empirical Assessment of Residents' Attitudes For Sustainable Tourism Development: A Case Study of O'Ahu, Hawai'i, Journal of Sustainability and Green Business, ss. 1-27.

Bahar, O. ve Kozak, M. (2006), Turizm Ekonomisi, Ankara: Detay Yayıncılık.

Baş, T. (2001), Anket, Ankara: Seçkin Yayıncılık.

Butler, R. W. (1980), 'The Concept Of A Tourist Area Cycle of Evolution: Implication For The Management of Resources', Canadian Geographer, (24) ss. 5-12.

Büyüköztürk, Ş. (2011), Sosyal Bilimler İçin Veri Analizi El Kitabı, Ankara: Pegem.

Cronbach, L. J. (1990), Essentials of Psychological Testing, New York: Harper \& Row.

Çeken, H. (2008), 'Turizmin Bölgesel Kalkınmaya Etkisi Üzerine Teorik Bir İnceleme', Afyon Kocatepe Üniversitesi I.I.B.F. Dergisi, ss. 293-306.

Çımat, A. ve Bahar, O. (2003), 'Turizm Sektörünün Türkiye Ekonomisi İçindeki Yeri ve Önemi Üzerine Bir Değerlendirme', Akdeniz I.I.B.F. Dergisi, (6), ss. 1-18.

Doka. (2014), TR90 Doğu Karadeniz Bölge Planı, Trabzon: Doğu Karadeniz Kalkınma Ajansı.

Dokap. (2014), Doğu Karadeniz Projesi (Dokap) Eylem Planı (2014-2018), T.C. Kalkınma Bakanlığı Doğu Karadeniz Projesi Bölge Kalkınma İdaresi Başkanlığı.

Durgun, A. (2006), Bölgesel kalkınmada Turizmin Rolü: Isparta Örneği, Basılmamış Yüksek Lisans Tezi, T.C. Süleyman Demirel Üniversitesi, Sosyal Bilimler Enstitüsü, Isparta.

Eren, R. ve Aypek, N. (2012), 'Kırsal Turizm Bölgesinde Yerel Halkın Turizmin Gelişimine Karşı Tutumları: Cumalıkızık Köyü Örneği', Uluslararası Sosyal ve Ekonomik Bilimler Dergisi, 2 (2), ss. 43-47.

Gökçen, A. (1987), 'Kalkınmada Öncelikli Yörelerde Uygulanan Gelişme Politikaları', İstanbul Üniversitesi Iktisat Fakültesi Dergisi, ss. 363-390.

Habing, B. (2003), Exploratory Factor Analysis, University of South Carolina.

Hair, J. F., Black, W. C., Babin, B. J., Anderson, R. E., ve Tatham, R. L. (2006), Multivariate Data Analysis, New Jersey: Prentice Hall.

İlban, M. O. ve Bezirgan, M. (2011), 'Yerli Turistlerin Destinasyon İmajı Algılarını Belirlemeye Yönelik Bir Araştırma: Burhaniye Örneği', 12. Ulusal Turizm Kongresi, ss. 52-60.

İlban, M. O., Akkılıç, M. E. ve Yılmaz, Ö. (2011), 'Termal Turizmde Tüketici Satın Alma Davranışını Etkileyen Faktörlerin Belirlenmesi: Gönen Örneği', Marmara Üniversitesi Öneri Dergisi, 36 (9), ss. 39-51.

Kayasü, S., Pınarcıoğlu, M., Suna, Y. S. ve Sencer, D. (2003), Yerel/Ekonomik Kalkınma ve Rekabet Gücünün Artırılması: Bölgesel Kalkınma Ajanslar, İstanbul Ticaret Odası, İstanbul.

Kızılırmak, İ. ve Kurtuldu, H. (2005), 'Kültürel Turizmin Önemi ve Tüketici Tercihlerinin Belirlenmesine Yönelik Bir Çalışma', Ticaret ve Turizm Eğitim Fakültesi Dergisi, (1), ss. 100-120.

Kök, N. F. (2010), Bölgesel Kalkınma Turizm İlişkisinde Kümelenmenin Rolü: Kavramsal Bir Analiz, Uzmanlık Tezi, T.C. Kültür ve Turizm Bakanlığı, Ankara.

Künü, S., Hopoğlu, S., Sökmen, Ö. ve Güneş, Ç. (2015), 'Turizm ve Bölgesel Kalkınma Arasındaki İlişki: Doğu Karadeniz Bölgesi Üzerine Bir İnceleme', Iğdır Üniversitesi Sosyal Bilimler Dergisi, (7), ss. 71-93.

Lankford, S. V. ve Howard, D. R. (1994), 'Developing a Tourism Impact Attitude Scale', Annals of Tourism Research, 21 (1), ss. 121-139. 
Okuyucu, A. ve Somuncu, M. (2012), 'Kültürel Mirasın Korunması ve Turizm Amaçlı Kullanılmasında Yerel Halkın Algı ve Tutumlarının Belirlenmesi: Osmaneli İlçe Merkezi Örneği', Ankara Üniversitesi Çevrebilimleri Dergisi, 4 (1), ss. 37-51.

Oskay, C. S. ve Kubar, Y. (2007), 'Avrupa Birliğine Uyum Sürecinde Türkiye'de Bölgesel Kalkınmanın Finansmanında Kalkınma ajansları', Selçuk Üniversitesi Karaman I.I.B.F Dergisi, ss. 204-214.

Özel, M. (2009), 'Avrupa Birliği'ne Uyum Sürecinde Türkiye'de Bölgelerarası Dengesizlik ve Yeni Yönetsel Birim Arayışları', Ankara Üniversitesi SBF Dergisi, 64 (1), ss. 165-199.

Özyücel, M. (2008), Avrupa Birliği Uyum Sürecinde Türkiye'de Uygulanan Kalkınma Politikaları, Basılmamış Yüksek Lisans Tezi, T.C. Süleyman Demirel Üniversitesi, Sosyal Bilimler Enstitüsü, Isparta.

Pallant, J. (2001), SPSS Survival Manual, Maryborough: McPherson's Printing Group.

Platania, S. ve Santisi, G. (2016), 'The Evaluation of the Impact of Tourism on Residents: The Case of Taormina', Mediterranean Journal of Social Sciences, 7 (2), ss. 88-97.

Savaş, F. V. (1979), Kalkınma Ekonomisi, İstanbul: Marmara Üniversitesi Nihad Sayar Eğitim Vakfı Yayınları.

Seltman, H. J. (2015), Experimental Design and Analysis, Carnegie Mellon University.

Szell, A. B. ve Hallett , L. F. (2013), 'Attitudes and Perceptions of Local Residents and Tourists toward the Protected Area of Retezat National Park, Romania', International Journal of Humanities and Social Science, 3 (4), ss. 18-34.

Tabachnick, B. G. ve Fidell, L. S. (2013), Using multivariate statistics, Boston: Pearson.

Toker, B. (2007), 'Türkiye'de Turizm Sektörü Teşviklerinin Değerlendirilmesi', Yönetim ve Ekonomi, 14 (2), ss. 81-92.

Tolunay, A. ve Akyol, A. (2006), 'Kalkınma ve Kırsal Kalkınma: Temel Kavramlar ve Tanımlar', Süleyman Demirel Üniversitesi Orman Fakültesi Dergisi, ss. 116-127.

Tutar, F. ve Demiral, M. (2007), 'Yerel Ekonomilerin Yerel Aktörleri: Bölgesel Kalkınma Ajansları', Eskişehir Osmangazi Üniversitesi IiBF Dergisi, 2 (1), ss. 65-83.

Türker, G. Ö. ve Türker, A. (2014), 'Yerel Halkın Turizm Etkilerini Algılama Düzeyi Turizm Desteğini Nasıl Etkiler: Dalyan Destinasyonu Örneği', Electronic Journal of Vocational Colleges, 4 (1), ss. 81-98.

Türkmen, F. ve Dönmez, Y. (2015), 'Korunan Alanların Turizme Açılmasına İlişkin Yerel Halkın Görüşleri', Karabük Üniversitesi Sosyal Bilimler Enstitüsü Dergisi, 5 (2), ss. 189-204.

Wang, Y. ve Pfister, R. E. (2008), 'Residents' Attitudes Toward Tourism and Perceived Personal Benefits in a Rural Community', Journal of Travel Research, (47), ss. 84-93.

Wang, Y., Pfister, R. E. ve Morais, D. B. (2006), 'Residents' Attitudes Toward Tourism Development: A Case Study of Washıngton NC', Proceedings of the 2006 Northeastern Recreation Research Symposium, ss. 411-418.

Woo, E., Uysal, M. ve Sirgy, J. M. (2016), 'Tourism Impact and Stakeholders' Quality of Life', Journal of Hospitality \& Tourism Research, ss. 1-27.

Yeşiltaş, M. ve Öztürk, İ. (2008), 'Bölgesel Kalkınma Çerçevesinde Alternatif Turizm Faaliyetlerine Yönelik Bir Değerlendirme: Sivas Örneği', C.Ü. Iktisadi ve Idari Bilimler Dergisi, 9 (1), ss. 1-18.

Internet Kaynakları

TDK, Türk Dil Kurumu Güncel Türkçe Sözlük: http://www.tdk.gov.tr, Erişim Tarihi:10.01.2016. 